\title{
Kondisi fisik dan suasana ruangan di Perpustakaan Fakultas Ekonomika dan Bisnis Universitas Gadjah Mada
}

\author{
Maryatun \\ Perpustakaan Universitas Gadjah Mada \\ Jl. Bulaksumur, Kotak Pos 16, Yogyakarta, 55281 \\ E-mail: maryatun@ugm.ac.id
}

Received: April 2018; Accepted: June 2018; Published: December 2018

\begin{abstract}
The collaborative learning atmosphere in higher education requires adequate facilities such as the availability of comfortable rooms and interior design according to the user needs. The purpose of the study was to discover the user's perceptions of the room's physical conditions, library facilities and identify spatial requirements, facilities, and the library's design facilities. This quantitative descriptive study used the purposive sampling technique. The 200 study samples obtained were students of the bachelor, master and doctoral study programs for the class of 2012, 2013, and 2014 who were still active as students. Results showed users' perceptions of the physical condition and atmosphere of the library room agreed on the strategic location, adequate and comfortable lighting system, besides it was beneficial during the study process. Library users required the addition of an independent study room separated from other spaces in the library, availability of electrical plug facility as well as the addition of WiFi. Most of the respondents required a desk in the self-study room, multimedia room, database/internet access room, shared space, support area, and a rectangular student workspace. The study group and discussion rooms required round shaped tables. The furniture's basic material is wood, and the basic colors are blue, except for the student workspace, which is a combination of brown and white. In conclusion, the users' perception of the Faculty of Economics and Business Library, Gadjah Mada University is that the location is strategic with adequate lighting. Users need additional selfstudy rooms and wooden furniture with a blue base color.
\end{abstract}

Keywords: Library room; Room facilities; Furniture design

\begin{abstract}
Abstrak
Atmosfir pembelajaran kolaboratif di perguruan tinggi memerlukan fasilitas yang memadai. Salah satunya tersedianya ruangan yang nyaman serta desain interior sesuai kebutuhan pemustaka. Tujuan penelitian ingin mengetahui persepsi pemustaka pada kondisi fisik ruangan, fasilitas perpustakaan serta mengidentifikasi kebutuhan tata ruang, fasilitas, dan desain fasilitas bagi pemustaka. Penelitian ini merupakan penelitian deskriptif kuantitatif. Pengambilan sampel dengan purposive sample. Sampel penelitian berjumlah 200 mahasiswa terdiri dari program studi S1, S2 dan S3 angkatan 2012, 2013, dan 2014 yang masih berstatus aktif sebagai mahasiswa. Hasil penelitian menunjukkan bahwa persepsi pemustaka pada kondisi fisik dan suasana ruangan perpustakaan menyetujui letak ruangan perpustakaan yang strategis, sistem pencahayaan di perpustakaan memadai, dan rasa nyaman dengan sistem pencahayaan di perpustakaan. Ruangan perpustakaan sangat bermanfaat selama proses studi. Pemustaka membutuhkan penambahan ruang belajar mandiri yang terpisah dengan ruang lain di perpustakaan, ketersediaan fasilitas stopkontak listrik serta penambahan kecepatan jaringan internet (WiFi). Sebagian besar responden membutuhkan desain perabot perpustakaan yang terdiri dari perabot meja pada ruang belajar mandiri, ruang multimedia, ruang akses database/internet, ruang bersama, area pelayanan bantuan dan ruang kerja mahasiswa berbentuk persegi panjang. Desain perabot meja untuk ruang belajar kelompok dan ruang diskusi berbentuk bulat. Bahan dasar perabot terbuat dari kayu serta warna dasar adalah warna biru, kecuali pada ruang kerja mahasiswa yaitu kombinasi warna coklat dan putih. Kesimpulan penelitian bahwa persepsi pemustaka pada perpustakaan Fakultas Ekonomika dan Bisnis Universitas Gadjah Mada mempunyai letak yang strategis dan pencahayaan memadai. Pemustaka memerlukan tambahan ruang belajar mandiri dan perabot dari kayu dengan warna dasar biru.
\end{abstract}

Kata kunci: Ruangan perpustakaan; Fasilitas ruangan; Desain perabot 


\section{PENDAHULUAN}

Sesuai dengan rencana pengembangan inovasi akademik (2015-2017) bahwa dalam 25 tahun ke depan visi Fakultas Ekonomika dan Bisnis Universitas Gadjah Mada (FEB UGM) adalah menjadi Fakultas Ekonomika dan Bisnis terbaik di Indonesia dan sangat disegani di Asia dalam memajukan pengajaran dan pengetahuan. Oleh karena itu, unit-unit yang berada di internal fakultas serta para stakeholder perlu memberikan dukungan penuh. Demikian juga perpustakaan FEB UGM, sebagai salah satu unit dari fakultas, berkewajiban mendukung tercapainya visi tersebut. Menurut Saunders (2016) menyatakan bahwa perpustakaan diharapkan dapat menyelaraskan kegiatannya dengan kegiatan lembaga induknya. Lebih khusus lagi bahwa perpustakaan mempunyai peran utama dalam mendukung pembelajaran mahasiswa di institusi (Tanloet \& Tuamsuk, 2011).

Perpustakaan FEB UGM berupaya untuk mewujudkan atmosfir pembelajaran kolaboratif dalam mendukung tercapainya visi fakultas dengan memberikan berbagai bentuk pelayanan bagi pemustaka dari tingkat mikro sampai makro baik secara fisik maupun virtual. Memberikan layanan teknis kepada pemustaka yang berkaitan dengan tugas akhir mahasiswa seperti pembuatan bookmark, pengelolaan sitasi, penelusuran informasi sesuai topik yang dibutuhkan pemustaka, serta menyediakan sebuah database yang memuat subyek - subyek mutakhir dan relevan dengan bidang penelitian civitas akademika. Selain itu, perpustakaan juga membantu proses penelitian dengan menyediakan sumber-sumber telaah informasi. Menurut Hernon (2016), "Libraries no longer play unique roles in their communities, as an environment of information scarcity has been replaced by the Internet and new communication and learning technologies". Perpustakaan harus ikut aktif mengetahuai mengenai penelitian para pemustakanya. Hal ini berhubungan dengan penelahaan koleksi perpustakaan yang dapat digunakan dalam penelitian tersebut, misalnya koleksi cetak dari textbook dan e-book, penelitian terdahulu dari karya ilmiah mahasiswa, dosen dan staf yang berbentuk cetak atau digital.

Atmosfir pembelajaran kolaboratif mensyaratkan fasilitas yang memadai. Bennet (2011) dalam Farmer (2016) menjelaskan bahwa, "Space was identified as the most important site. Libraries provided the conditions for students to self-direct their learning and research more than other venues; libraries combined both open-ended environments and planned functional structure. In reviewing the role of the library in academia". Fasilitas ruangan sangat penting dalam menunjang pembelajaran akademik. Maka, perpustakaan sebagai lembaga sumber informasi, merancang ruangan yang nyaman dan menyediakan ruang khusus belajar pemustaka.

Berkaitan dengan fasilitas fisik yang harus disediakan oleh perpustakaan, Wiratningsih (2015) menyebutkan bahwa perpustakaan harus menyediakan ruangan-ruangan untuk, "reading, private study, discussion (group and individual), printing and copying, multimedia room, dan consultation/information desk". Setiap ruangan didesain dengan sentuhan teknologi yang disesuaikan dengan fungsi masing-masing ruangan.

Pembagian ruang perpustakaan belum dilakukan sesuai fungsinya. Ruang belajar mandiri (quite area) masih menjadi satu dengan ruang koleksi, akibatnya pemustaka yang sedang belajar terganggu dengan hilir mudik pemustaka yang 
sedang mencari buku di rak. Selain itu, ruang yang disediakan untuk belajar kelompok menjadi satu dengan area pemustaka yang mengakses database EBDL (Economics and Business Digital Library). Database EBDL memuat karya tulis berupa Skripsi, Tesis, dan Disertasi. Pada umumnya pemustaka yang mengakses EBDL memerlukan konsentrasi untuk dapat memahami isi sebuah karya tulis. Namun demikian suasana ruangan tidak mendukung aktivitas pemustakanya. Hal tersebut diakibatkan oleh suara gaduh yang ditimbulkan oleh pemustaka yang sedang berdiskusi atau mengerjakan tugas kelompok.

Sudah tidak jamannya lagi petugas perpustakaan memberikan larangan untuk berbicara keras di perpustakaan. Pemustaka sekarang berbeda dengan pemustaka zaman dahulu. Pemustaka sekarang sebagian besar merupakan generasi Net atau Generasi Z, yaitu menurut Tapscott (2008) dalam Istiqomah (2014), menyatakan bahwa generasi yang lahir tahun 1977-1997, teknologi internet sudah menjadi bagian hidupnya dengan salah satu karakternya adalah mereka menginginkan kebebasan; bebas memilih sampai bebas berekspresi. Mereka membutuhkan tempat nyaman yang dapat memfasilitasi aktivitasnya untuk menciptakan ide-ide baru sekaligus sebagai tempat untuk bersosialisasi.

Perpustakaan Nasional R.I. (2011) menyebutkan bahwa Standar Nasional Perpustakaan (SNP) 010:2011, memuat standar tentang sarana dan prasarana yang meliputi luasan ruang, komposisi ruang, dan pengaturan kondisi ruangan yang harus disediakan oleh perpustakaan perguruan tinggi. Pengaturan kondisi ruangan dilakukan dengan cara mengendalikan kondisi ruangan dalam pencahayaan, kelembaban, dan temperatur ruangan. Sebuah perpustakaan yang memiliki struktur bangunan dan ruangan yang baik serta bahan pustaka yang tertata rapi akan memberikan kenyamanan dan kepuasan bagi pustakawan dan pemustaka (Anugrah \& Ardoni, 2013). Selanjutnya untuk desain perabot perpustakaan perlu mempertimbangkan kesederhanaan, keluwesan, fungsional, dan faktor ergonomi. Perabot perpustakaan akan mempengaruhi suasana kenyamanan dan keamanan pemustaka dalam memanfaatkan perpustakaan. Selain itu, suasana nyaman dan aman juga dipengaruhi oleh temperatur, kelembaban, sirkulasi udara, pencahayaan, getaran mekanis, warna, dan bau. Sementara itu, The Association of College and Research Libraries (ACRL) (2004) dalam Nitecki (2011) memberikan standar persyaratan untuk fasilitas perpustakaan yang harus direncanakan dengan baik, antara lain ruangan perpustakaan harus meliputi ruangan yang memadai dan aman, kondusif untuk belajar dan penelitian, serta mempunyai kondisi yang nyaman untuk pelayanan, staf, sumberdaya, dan koleksi.

Le (2009) menyatakan perpustakaan harus memfokuskan pelayanannya dalam pengembangan pembelajaran serta tumbuhnya inovasi. Salah satunya menciptakan ruang perpustakaan fungsional serta memiliki nilai tambah. Bagi pemustaka yang terbiasa hidup di dunia yang serba cepat, sibuk, dan hingarbingar maka perpustakaan merupakan pilihan yang menawarkan keunikan sebagai tempat "persembunyian" untuk berpikir, melakukan refleksi, dan bersosialisasi. Desain ulang ruang perpustakaan mencerminkan transformasi 
perpustakaan menjadi pusat sosial untuk belajar, berinovasi, dan berjejaring. Montgomery (2014) berpendapat bahwa telah terjadi perubahan akses informasi. Pemustaka dengan mudah melakukan akses informasi dari luar gedung perpustakaan. Oleh karena itu, perlu desain ulang untuk menciptakan ruang baru yang dapat merespon kebutuhan pemustaka. Hal tersebut sesuai dengan Turner, Welch, and Reynolds (2013) yang menyatakan bahwa perpustakaan perlu menyediakan berbagai ruang yang sifatnya formal maupun informal dengan fasilitas yang lebih baik dan fleksibel.

Saat ini, ada tiga hal yang membuat kita harus memikirkan kembali perlunya perubahan fisik dan tata ruang perpustakaan. Tiga hal tersebut antara lain: 1) perubahan kebiasaan dan perilaku pemustaka karena munculnya media baru; 2) perubahan sumber daya dan tugas baru di perpustakaan; dan 3) perubahan proses kerja dari manual ke otomasi, termasuk berkembangnya berbagai fasilitas pelayanan mandiri (Niegaard, 2011). Pemustaka sekarang sebagian besar merupakan generasi digital. Generasi yang memerlukan berbagai fasilitas seperti, outlet listrik, WiFi/hotspot, kecepatan akses internet, perabotan yang informal dan santai, dan fasilitas audio video. Di samping itu dalam mendesain penataan ruangan hendaknya memberikan ruang lebih bagi pemustaka agar dapat saling berinteraksi dan kolaborasi (Istiqomah, 2014).

Achmad, Sutedjo, Surono, dan Suprayitno (2012) dan Widjaja (2009) menyatakan bahwa gedung atau ruang perpustakaan hendaknya fashionable, yaitu yang mengikuti arsitektur dan desain interior saat ini, termasuk dalam pemilihan warna. Motealleh, Parsaee, \&
Sheybani (2015) menyatakan bahwa area perpustakaan harus dapat membantu pemustaka untuk mengurangi stres, meningkatkan relaksasi, dan meningkatkan konsentrasi ketika mereka sedang belajar.

Pemanfaatan ruang yang ada di dalam perpustakaan sebagai area atau tempat yang nyaman bagi pemustaka dalam melakukan kegiatan pembelajaran, penelitian, maupun kegiatan yang sifatnya santai didefinisikan sebagai istilah learning commons (Kumalawati, 2015).

Beberapa penelitian yang membahas tentang pentingnya tata ruang, suasana ruang, fasilitas, serta desain perpustakaan, antara lain:

Beard and Bawden (2012) dalam penelitiannya menemukan bahwa inovasi area atau ruang perpustakaan dan kebutuhan untuk pengembangan kegiatan pembelajaran sangat diperlukan. Hal tersebut didukung oleh penelitian Matthews and Walton (2014) yang menyatakan bahwa area/ruang fisik perpustakaan perguruan tinggi mempunyai peran yang sangat penting dalam kegiatan pembelajaran dan penelitian, di samping pustakawan dan sumber informasi digital. Chan and Spodick (2014) dalam penelitiannya menyatakan dalam era digital, perpustakaan perguruan tinggi dapat berubah pada hal-hal baru yang diintegrasikan dengan teknologi desain yang fleksibel dan area baru yang lebih menarik untuk menyesuaikan karakter pemustaka. Beard and Bawden (2012) menyimpulkan bahwa mahasiswa pasca sarjana lebih membutuhan ruang atau area belajar yang tenang. Mereka sangat antusias dalam meminjam buku dan kurang tertarik dalam pemanfaatan sosial media di perpustakaan. 
Noviani, Rusmana, dan Rodiah (2014) dalam penelitian tentang desain interior perpustakaan dalam menumbuhkan minat baca pada ruang perpustakaan menunjukkan bahwa furnitur dan aksesori dari perpustakaan berperan penting dalam menumbuhkan minat ke perpustakaan. Warna-warna, pencahayaan, dan sirkulasi udara berperan penting dalam menumbuhkan minat ke perpustakaan.

Sementara itu, Yoo-Lee, Lee, and Velez (2013) mengungkapkan temuan bahwa mahasiswa seringkali memanfaatkan area perpustakaan untuk berbagai aktivitas mulai dari mengerjakan tugas secara mandiri sampai bekerja kolaboratif dengan menggunakan perangkat teknologi. Bailin (2011) mengeksplorasi pemanfaatan ruang belajar bersama, ruang belajar mandiri, desain ruang, ruang untuk bertemu atau berkumpul dengan teman, pemanfaatan teknologi, tingkat kegaduhan suara, serta area bantuan informasi. Andrews, Wright, and Raskin (2015) dalam penelitiannya menyatakan bahwa perpustakaan merupakan tempat yang memberikan inspirasi siswa untuk belajar. Mereka membutuhkan teknologi yang terintegrasi dan menginginkan furnitur yang nyaman dalam berbagai bentuk dan warna. Saunders (2015) melakukan analisis isi dari 63 rencana strategis yang diliput pada ACRL National Summits, bahwa area fisik perpustakaan menempati urutan kedua dari rencana strategis yang disusun oleh berbagai perpustakaan setelah koleksi. Fasilitas dalam area fisik perpustakaan menjadi rencana strategis yang paling populer. Beberapa rencana umumnya membicarakan tentang fasilitas yang nyaman, menarik, dan aman untuk digunakan. Selain itu, tujuan spesifiknya antara lain menyediakan ruang pertemuan untuk belajar kelompok atau ruang belajar mandiri, dan menyediakan perabot dan perlengkapan yang dibutuhkan untuk belajar dan penelitian, serta ruang virtual untuk komunitasnya.

Berdasarkan uraian latar belakang masalah dalam penelitian ini, maka tujuan penelitian adalah untuk: (1) Mengetahui persepsi pemustaka pada kondisi fisik dan suasana ruangan di Perpustakaan FEB UGM UGM, (2) Mengetahui persepsi pemustaka pada tata ruang dan fasilitas perpustakaan saat ini, (3) Mengetahui apakah kondisi fisik, suasana, tata ruang, dan fasilitas perpustakaan perlu ditingkatkan, (4) Mengetahui tata ruang yang dibutuhkan oleh pemustaka, (5) Mengetahui fasilitas yang dibutuhkan oleh pemustaka, dan (6) Mengetahui desain fasilitas yang dibutuhkan oleh pemustaka.

Berdasarkan pada keterbatasan ruang dan tata letak internalnya, Perpustakaan FEB UGM perlu memperluas persediaan kebutuhan ruang sehingga mewadahi bagi kebutuhan pemustaka. Penelitian kebutuhan ruang di Perpustakaan FEB belum pernah dilakukan oleh peneliti sebelumnya.

\section{METODE PENELITIAN}

Penelitian ini menggunakan jenis penelitian deskriptif yang dilakukan di Perpustakaan FEB UGM dengan teknik pengambilan sampel purposive sample (sampel bertujuan). Sampel dalam penelitian ini adalah Mahasiswa S1, S2 dan S3 Fakultas Ekonomika dan Bisnis UGM angkatan 2012, 2013, dan 2014 yang masih berstatus aktif sebagai mahasiswa. Jumlah sampel sebanyak 200 mahasiswa. Alat ukur dalam penelitian ini adalah: 1) Persepsi pemustaka pada kondisi fisik dan suasana ruangan perpustakaan, 2) Persepsi pemustaka pada tata ruang dan fasilitas 
perpustakaan saat ini, 3) Kebutuhan tata ruang perpustakaan untuk pemustaka, 4) Kebutuhan fasilitas ruangan perpustakaan untuk pemustaka, dan 5) Kebutuhan desain fasilitas ruangan perpustakaan untuk pemustaka. Alat ukur tersebut kemudian dituangkan dalam item pertanyaan atau pernyataan dengan memodifikasi beberapa indikator penelitian yang digunakan oleh peneliti sebelumnya. Beberapa item pernyataan yang memuat jawaban yang dibuat dengan menggunakan Skala Likert.

Uji instrumen diolah dengan SPSS versi 22. Nilai rerata jawaban responden pada setiap variabel dikelompokkan ke dalam 4 (empat) kategori penafsiran, 1) Nilai rerata 1,00 - 2,00 tidak setuju dengan pernyataan, 2) Nilai rerata 2,01 - 3,00 kurang setuju dengan pernyataan, 3) Nilai rerata 3,01 - 4,00 cukup setuju dengan pernyataan, dan 4) Nilai rerata 4,01 - 5,00 setuju dengan pernyataan.

\section{HASIL DAN PEMBAHASAN}

Hasil analisis deskriptif responden yang mengisi kuesioner berjumlah 200 mahasiswa. Data responden berdasar jenis kelamin terbanyak adalah wanita sebanyak 130 mahasiswa (65\%), sedangkan pria sebanyak 70 mahasiswa (35\%). Data responden menurut jenjang studi terbanyak adalah S1 sebanyak 187 mahasasiswa (93,5\%). Kemudian menurut jurusan terbanyak adalah akuntansi sebanyak 90 mahasiswa (47,5\%) dan angkatan 2014 merupakan responden yang terbanyak 99 mahasiswa (49,5\%).

Perpustakaan FEB UGM menempati tiga (3) ruangan di sayap utara lantai 1 yang merupakan bagian dari bangunan gedung fakultas. Jadi secara fisik kelihatan bahwa ruangan perpustakaan tidak didesain sebagai perpustakaan yang mempunyai berbagai ruangan dengan fungsinya masing-masing.

Persepsi pemustaka pada kondisi fisik dan suasana ruangan perpustakaan dapat dilihat pada tabel 1, bahwa persepsi pemustaka dilihat dari letak ruangan perpustakaan strategis, kondisi fisik ruangan perpustakaan yang menarik, kondisi fisik ruangan perpustakaan yang memadai, Ketersediaan peralatan TI, Ketersediaan buku, tata suara, pencahayaan, dan sirkulasi udara, serta kenyamanan pencahayaan dan sirkulasi di perpustakaan.

\section{Tabel 1}

Persepsi pemustaka pada kondisi fisik dan suasana ruangan perpustakaan

\begin{tabular}{lll}
\hline No & Pernyataan & $\begin{array}{l}\text { Nilai } \\
\text { mean }\end{array}$ \\
\hline 1. & $\begin{array}{l}\text { Letak ruangan perpustakaan } \\
\text { strategis }\end{array}$ & 4,00 \\
2. & $\begin{array}{l}\text { Kondisi fisik ruangan } \\
\text { perpustakaan menarik }\end{array}$ & 3,63 \\
3. & $\begin{array}{l}\text { Ketersediaan ruangan } \\
\text { perpustakaan memadai }\end{array}$ & 3,03 \\
4. & $\begin{array}{l}\text { Ketersediaan peralatan TI di } \\
\text { perpustakaan memadai }\end{array}$ & 3,04 \\
5. & $\begin{array}{l}\text { Ketersediaan buku di } \\
\text { perpustakaan memadai } \\
\text { 6. }\end{array}$ & $\begin{array}{l}\text { Susunan buku di rak terlihat rapi } \\
\text { dan teratur }\end{array}$ \\
7. & $\begin{array}{l}\text { Sistem tata suara di } \\
\text { perpustakaan memadai }\end{array}$ \\
8. & $\begin{array}{l}\text { Saya merasa nyaman dengan tata } \\
\text { suara di perpustakaan }\end{array}$ & 3,59 \\
9. & $\begin{array}{l}\text { Sistem pencahayaan di } \\
\text { perpustakaan memadai }\end{array}$ \\
10. & $\begin{array}{l}\text { Saya merasa nyaman dengan } \\
\text { sistem pencahayaan di }\end{array}$ & 4,42 \\
perpustakaan & 4,08 \\
11. & $\begin{array}{l}\text { Sistem sirkulasi udara di } \\
\text { perpustakaan memadai }\end{array}$ \\
12. & $\begin{array}{l}\text { Saya merasa nyaman dengan } \\
\text { sistem sirkulasi udara di } \\
\text { perpustakaan }\end{array}$ & 3,95 \\
\hline
\end{tabular}

Sumber: Hasil penelitian, 2018 
Tabel 1 menunjukkan bahwa letak ruangan perpustakaan strategis dengan nilai mean 4. Lokasi perpustakaan yang terletak di lantai 1 (satu) dan dekat dengan pintu masuk gedung fakultas merupakan lokasi yang sangat strategis. Pemustaka tidak perlu naik turun tangga untuk ke perpustakaan. Pada pagi hari sebelum jam buka perpustakaan kondisi ruangan yang sudah bersih dan pencahayaan yang cukup terang menarik pemustaka untuk segera masuk ke perpustakaan. Responden setuju dengan pernyataan bahwa sistem pencahayaan di perpustakaan memadai, dan merasa nyaman dengan sistem pencahayaan di perpustakaan yang ditunjukkan rerata nilai lebih dari 4,10. Sistem pencahayaan khususnya di perpustakaan unit satu dengan memasang beberapa lampu yang cukup terang memberikan kenyamanan pemustaka. Hal tersebut ditunjukkan dengan nilai rerata sebesar 4,08. Selain itu juga didukung kecekatan tenaga teknisi yang segera memperbaiki atau mengganti lampu apabila ada yang rusak atau mati.

Selanjutnya responden cukup setuju dengan beberapa pernyataan yang ditunjukkan dengan rerata nilai 3,00 - 4,00. Meskipun penilaian responden tentang ketersediaan ruangan perpustakaan termasuk pada kategori cukup memadai, namun apabila dibandingkan dengan indikator lain tentang persepsi pemustaka pada kondisi fisik dan suasana ruangan perpustakaan maka responden memberikan penilaian yang paling rendah, yaitu 3,03 untuk pernyataan ketersediaan ruang perpustakaan memadai. Demikian juga dengan penilaian responden pada pernyataan ketersediaan peralatan TI di perpustakaan, responden memberikan rerata nilai 3,04 atas pernyataan tersebut. Artinya, responden mengharapkan bahwa ketersediaan ruangan dan peralatan TI yang ada di perpustakaan perlu lebih mendapatkan perhatian untuk penambahan atau pengembangan lebih lanjut. Ketersediaan ruangan perpustakaan masih belum memadai karena selama ini belum pernah ada penambahan ruangan perpustakaan, sementara kebutuhan ruang terus bertambah karena jumlah mahasiswa yang bertambah. Di samping itu adanya perubahan pola belajar mahasiswa yang mensyaratkan tempat yang lebih leluasa untuk berdiskusi, belajar kelompok, atau hanya sekedar untuk bertemu teman.

Ketersediaan ruangan perpustakaan yang terbatas juga akan mempengaruhi penempatan beberapa peralatan teknologi informasi. Penambahan komputer untuk mengakses internet dan data osiris tidak dapat dilakukan karena tempat terbatas. Komputer untuk mengakses katalog koleksi perpustakaan hanya tersedia satu unit komputer. Akibatnya sering terjadi antrian mahasiswa yang hanya untuk sekedar mengecek ketersediaan buku di perpustakaan. Walaupun untuk mengecek ketersediaan buku perpustakaan dapat dilakukan di luar ruang perpustakaan yang dapat diakses melalui website fakultas maupun perpustakaan. Pemustaka kadang kurang memahami bahwa informasi yang mereka butuhkan dapat diakses dengan mudah di manapun dan kapan pun sehingga pemustaka tidak perlu mengantri hanya sekedar untuk mengecek ketersediaan buku.

Selain kondisi fisik dan suasana ruangan perpustakaan, tata ruang dan fasilitas ruangan perpustakaan akan mempengaruhi pemustaka dalam memanfaatkan pelayanan perpustakaan. Persepsi Pemustaka pada Tata Ruang dan Fasilitas Ruangan Perpustakaan FEB UGM 
dapat dilihat pada tabel 2, bahwa persepsi pemustaka dilihat dari keleluasaan beraktivitas di perpustakaan, kemudahan mencari buku di rak, kemudahan penjangkauan buku, kebermanfataan ruangan perpustakaan, ketersediaan meja baca, kursi baca dan komputer di perpustakaan, keteraturan susunan rak, ketersediaan display buku, loker dan stopkontak, dan penempatan fasilitas perpustakaan.

\section{Tabel 2}

Persepsi pemustaka pada tata ruang dan fasilitas ruangan perpustakaan

\begin{tabular}{|c|c|c|}
\hline No & Pernyataan & $\begin{array}{l}\text { Nilai } \\
\text { mean }\end{array}$ \\
\hline 1. & $\begin{array}{l}\text { Saya leluasa dalam bergerak } \\
\text { selama beraktivitas di } \\
\text { perpustakaan }\end{array}$ & 3,30 \\
\hline 2. & $\begin{array}{l}\text { Saya mudah untuk mencari } \\
\text { buku di rak }\end{array}$ & 3,43 \\
\hline 3. & $\begin{array}{l}\text { Jarak rak buku dan meja } \\
\text { peminjaman tidak terlalu jauh }\end{array}$ & 3,78 \\
\hline 4. & $\begin{array}{l}\text { Ruangan di perpustakaan } \\
\text { bermanfaat selama proses } \\
\text { studi saya }\end{array}$ & 4,11 \\
\hline 5. & $\begin{array}{l}\text { Ketersediaan meja baca di } \\
\text { perpustakaan memadai }\end{array}$ & 2,77 \\
\hline 6. & $\begin{array}{l}\text { Ketersediaan kursi baca di } \\
\text { perpustakaan memadai }\end{array}$ & 2,74 \\
\hline 7. & $\begin{array}{l}\text { Ketersediaan komputer di } \\
\text { perpustakaan memadai }\end{array}$ & 2,55 \\
\hline 8. & $\begin{array}{l}\text { Susunan rak di perpustakaan } \\
\text { terlihat teratur }\end{array}$ & 3,87 \\
\hline 9. & $\begin{array}{l}\text { Ketersediaan rak display buku } \\
\text { di perpustakaan memadai }\end{array}$ & 3,58 \\
\hline 10. & $\begin{array}{l}\text { Ketersediaan loker di } \\
\text { perpustakaan memadai }\end{array}$ & 3,28 \\
\hline 11. & $\begin{array}{l}\text { Ketersediaan stopkontak listrik } \\
\text { di perpustakaan memadai }\end{array}$ & 3,00 \\
\hline 12. & $\begin{array}{l}\text { Penempatan fasilitas } \\
\text { perpustakaan terlihat rapi }\end{array}$ & 3,90 \\
\hline
\end{tabular}

Sumber: Hasil penelitian, 2018

Dari tabel 2, menunjukkan keberadaan Perpustakaan FEB UGM sebagai unit penunjang kegiatan dalam belajar mengajar telah dirasakan manfaatnya oleh pemustaka. Beberapa fasilitas pelayanan yang disediakan perpustakaan dimanfaatkan dengan baik. Hal tersebut ditunjukkan dengan penilaian responden bahwa ruangan di perpustakaan bermanfaat selama proses studi saya, dengan rerata nilai 4,11 .

Selanjutnya responden cukup setuju dengan beberapa pernyataan yang ditunjukkan dengan rerata nilai 3,00 - 4,00 diantaranya responden masih cukup leluasa dalam bergerak selama beraktivitas di perpustakaan, mudah untuk mencari buku di rak, jarak rak buku dan meja peminjaman tidak terlalu jauh, susunan rak di perpustakaan terlihat teratur, ketersediaan rak display buku, jumlah loker yang tersedia, penempatan beberapa fasilitas perpustakaan seperti meja, kursi, rak buku, dan komputer untuk mengakses informasi dan fasilitas lainnya terlihat cukup rapi. Staf perpustakaan secara berkala mengecek susunan buku di rak. Kemungkinan buku tidak pada urutan nomor klasifikasinya. Hal tersebut dapat disebabkan karena pemustaka menempatkan sendiri koleksi buku yang selesai dibaca atau buku yang tidak jadi dipinjam. Selain itu, juga merupakan salah satu kelemahan sistem pelayanan perpustakaan yang menggunakan sistem pelayanan terbuka.

Fasilitas fisik berupa meja dan kursi pemanfaatanya sudah melebihi kapasitas sehingga responden memberikan penilaian kurang setuju bahwa ketersediaan meja baca, kursi baca, dan ketersediaan komputer di perpustakaan memadai dengan rerata nilai di bawah 3,00. Fasilitas lain di perpustakaan adalah ketersediaan stopkontak listrik di perpustakaan. Responden memberikan penilaian bahwa stopkontak yang ada di perpustakaan kurang memadai. Sebagian 
besar pemustaka menggunakan laptop ketika di perpustakaan. Jumlah stopkontak yang ada di perpustakaan tidak sebanding dengan kursi baca yang tersedia.

Tata ruang akan mempengaruhi aktivitas orang-orang yang berada di dalamnya. Tata ruang perpustakaan yang baik akan menimbulkan kenyamanan pemustaka selama melakukan aktivitas di perpustakaan. Tata ruang perpustakaan yang dibutuhkan pemustaka dapat dilihat pada tabel 3.

Tabel 3

Kebutuhan tata ruang perpustakaan untuk pemustaka

\begin{tabular}{|c|c|c|}
\hline No & Pernyataan & $\begin{array}{l}\text { Nilai } \\
\text { mean }\end{array}$ \\
\hline 1. & $\begin{array}{l}\text { Ruang untuk belajar mandiri } \\
\text { terpisah dengan ruang lain di } \\
\text { perpustakaan }\end{array}$ & 4,01 \\
\hline 2. & $\begin{array}{l}\text { Ruang untuk belajar kelompok } \\
\text { terpisah dengan ruang lain di } \\
\text { perpustakaan }\end{array}$ & 3,97 \\
\hline 3. & $\begin{array}{l}\text { Ruang untuk diskusi terpisah } \\
\text { dengan ruang lain di } \\
\text { perpustakaan }\end{array}$ & 3,93 \\
\hline 4. & $\begin{array}{l}\text { Ruang untuk akses database dan } \\
\text { internet terpisah dengan ruang } \\
\text { lain di perpustakaan }\end{array}$ & 3,36 \\
\hline 5. & $\begin{array}{l}\text { Ruang multimedia terpisah } \\
\text { dengan ruang lain di } \\
\text { perpustakaan }\end{array}$ & 3,46 \\
\hline 6. & $\begin{array}{l}\text { Ruang bersama (lounge area) } \\
\text { terpisah dengan ruang lain di } \\
\text { perpustakaan }\end{array}$ & 3,59 \\
\hline 7. & $\begin{array}{l}\text { Ruang untuk kerja mahasiswa } \\
\text { terpisah dengan ruang lain di } \\
\text { perpustakaan }\end{array}$ & 3,50 \\
\hline 8. & $\begin{array}{l}\text { Area pelayanan bantuan (help } \\
\text { zone) untuk memanfaatkan } \\
\text { sumberdaya perpustakaan } \\
\text { terpisah dengan ruang lain di } \\
\text { perpustakaan }\end{array}$ & 3,27 \\
\hline
\end{tabular}

Sumber: Hasil penelitian 2018

Dari tabel 3, menunjukkan bahwa responden setuju bahwa ruang untuk belajar mandiri terpisah dengan ruang lain di perpustakaan. Hal tersebut ditunjukkan dengan rerata nilai 4,01. Ruang belajar mandiri (quite area) digunakan pemustaka agar lebih berkonsentrasi dalam belajar. Pemustaka yang belajar di ruang mandiri tergganggu oleh pemustaka yang sedang mencari buku di rak. Selain itu, penempatan stopkontak listrik di bagian bawah rak buku juga sering mengganggu pemustaka yang belajar mandiri karena khawatir kabel yang menghubungan stopkontak dan laptop mudah lepas. Sebaliknya kabel tersebut juga mengganggu pemustaka yang mencari buku khususnya buku berbahasa Indonesia. Beberapa stopkontak menempel di rak bagian bawahnya yang memungkinkan dapat menjerat kaki pemustaka yang sedang mencari buku. Sementara itu responden juga cukup setuju dengan beberapa pernyataan dengan memberikan rerata nilai 3,27 sampai 3,97. Pernyataan tersebut di antaranya ruang untuk belajar kelompok terpisah dengan ruang lain di perpustakaan, ruang untuk diskusi terpisah dengan ruang lain di perpustakaan, ruang multimedia, ruang bersama (lounge area) terpisah dengan ruang lain di perpustakaan, ruang untuk kerja mahasiswa yang letaknya terpisah dengan ruang lain di perpustakaan, dan area pelayanan bantuan (help zone) untuk memanfaatkan sumberdaya perpustakaan terpisah dengan ruang lain di perpustakaan. Namun apabila dilihat dari rerata nilai dari variabel kebutuhan tata ruang perpustakaan untuk pemustaka, maka area pelayanan bantuan yang letaknya terpisah dengan ruang lain di perpustakaan mempunyai rerata nilai terendah yaitu 3,27. Artinya, responden mengharapkan area pelayanan bantuan mudah diakses walaupun terpisah dengan 
ruang lain di perpustakaan. Kebutuhan ruang kerja mahasiswa, ruang untuk akses internet dan database, serta ruang multimedia sebaiknya dekat dengan area pelayanan bantuan (help zone) sehingga apabila ada permasalahan dengan pemanfaatan ruang tersebut dapat segera diselesaikan.

Kebutuhan tata ruang perpustakaan untuk pemustaka seperti ruang diskusi dan ruang belajar kelompok memerlukan kapasitas tempat duduk yang ideal agar dapat berfungsi optimal. Responden terbesar (48\%) membutuhkan tempat duduk untuk satu ruang diskusi terdiri 5 7 orang. Kemudian 28,5\% responden menyatakan bahwa satu ruang diskusi terdiri 8 - 10 orang, 12,5\% responden membutuhkan kapasitas ruang diskusi terdiri lebih dari 10 orang, dan 11\% membutuhkan kapasitas satu ruang diskusi terdiri dari 3 - 4 orang. Selanjutnya, kebutuhan kapasitas tempat duduk untuk belajar kelompok, jumlah responden sebanyak 50\% memerlukan tempat duduk untuk belajar kelompok terdiri dari 5 - 7 orang. Kemudian 32\% responden menyatakan bahwa ruang belajar kelompok dengan kapasitas 8 - 10 orang, $13 \%$ responden membutuhkan kapasitas ruang belajar kelompok terdiri dari 3 - 4 orang, dan 3\% membutuhkan kapasitas lebih dari 10 orang.

Ruang belajar mandiri yang ada di Perpustakaan FEB UGM sebenarnya merupakan ruang baca koleksi perpustakaan. Pemustaka dapat memanfaatkan meja dan kursi yang berada di sebelah rak buku untuk mengecek kebenaran buku yang akan dipinjam. Beberapa peminjam kadang mengembalikan buku yang baru saja dipinjam dengan alasan buku tidak sesuai dengan yang dibutuhkan. Oleh karena itu, perpustakaan perlu menyediakan ruang belajar mandiri agar pemustaka lebih nyaman dalam belajar di perpustakaan. Responden juga mengusulkan beberapa ruang yang mereka butuhkan, antara lain ruang baca dengan meja sekat, ruang baca "lesehan" dengan karpet, ruangan yang diperbolehkan untuk membawa makanan dan minuman, serta dilengkapi fasilitas kantin atau kafe.

Pemustaka memerlukan berbagai fasilitas di setiap ruang. Fasilitas stop contact/stopkontak listrik serta jaringan internet/Wi-Fi di setiap tempat sudah menjadi kebutuhan. Kebutuhan fasilitas masing-masing ruang di perpustakaan untuk pemustaka minimal ada fasilitas meja, kursi, Wi-Fi, dan stopkontak listrik. Kemudian masing-masing ruang atau area perlu penambahan fasilitas lain sesuai fungsinya. Ruang belajar mandiri memerlukan tambahan fasilitas komputer, Alat Tulis Kantor (ATK), dan sofa. Perbedaan jenjang pendidikan akan berpengaruh pada kebutuhan fasilitas yang harus disediakan oleh perpustakaan. Pemustaka dengan jenjang pendidikan S2/S3 pada umumnya perlu disediakan fasilitas sesuai kebiasaan cara belajarnya yaitu, ruang belajar yang sunyi dan meja bersekat. Sementara itu, pemustaka dengan jenjang pendidikan S1 dengan usia yang relatif lebih muda membutuhkan ruang belajar mandiri yang sifatnya lebih santai. Mereka sudah terbiasa belajar sambil mendengarkan musik dengan posisi berbaring, bersila sehingga membutuhkan sofa yang nyaman sebagai tempat duduk. Ruang belajar kelompok membutuhkan tambahan fasilitas white board, ATK, dan komputer. Fasilitas white board sangat penting untuk ruang belajar kelompok karena ketua kelompok akan mudah menjelaskan materi yang harus 
dibahas oleh setiap anggota kelompok. Apabila tersedia anggaran yang besar untuk pengembangan perpustakaan, ketersediaan layar LCD dapat dihubungkan dengan komputer atau laptop yang dibawa sendiri oleh pemustaka. Hasil kerja kelompok dapat disimpan secara otomatis tanpa harus dicatat sehingga pekerjaan akan lebih efisien. Sama halnya dengan ruang diskusi, ruangan ini memerlukan tambahan fasilitas yang lebih lengkap dan modern. Belajar di ruang diskusi tidak harus duduk di kursi dengan susunan meja yang formal. Pemustaka dengan usia yang lebih muda membutuhkan karpet untuk duduk yang lebih santai di ruang diskusi. Sementara itu, ruang multimedia membutuhkan fasilitas TV screen, DVD/Video player, komputer, dan head set. Di Perpustakaan FEB UGM memang sebelumnya belum mempunyai ruang multimedia yang bersatu dengan koleksi perpustakaan. Rencananya ke depan, perpustakaan akan memiliki koleksi multimedia yang berisi kasus-kasus bisnis di dunia, rekaman kegiatan pembelajaran yang dapat diakses oleh mahasiswa yang ingin mengulang atau mendalami suatu mata kuliah tertentu. Mereka perlu disediakan sarana akses berbagai media pembelajaran untuk dilihat bersama atau secara mandiri. Ruang akses internet atau database memerlukan fasilitas tambahan berupa printer dan head set. Ruang bersama memerlukan fasilitas sofa, TV, karpet, dispenser, dan koran/majalah. Ruangan ini sangat cocok digunakan mahasiswa untuk bersantai setelah mengikuti kuliah. Area pelayanan bantuan dan ruang kerja mahasiswa membutuhkan tambahan fasilitas printer, mesin fotokopi, scanner, dan ATK.
Setiap ruangan perpustakaan dapat bermanfaat optimal apabila didukung fasilitas yang tersedia di dalamnya. Beberapa hal yang menjadi perhatian untuk memenuhi kebutuhan fasilitas ruangan tersebut berkaitan dengan alokasi anggaran untuk pengadaan berbagai peralatan, perawatan fasilitas, serta pengawasan pemakaian peralatan tersebut. Yang lebih penting lagi adalah tersedianya petunjuk atau bimbingan pengoperasian fasilitas yang baik dan benar.

Kebutuhan kecepatan Wi-Fi di setiap ruangan memerlukan komunikasi yang intensif dengan Direktorat Sistem dan Sumberdaya Informasi (DSSDI) UGM. Direktorat tersebut adalah pihak yang mempunyai kewenangan mengatur kecepatan akses Wi-Fi di setiap fakultas.

Selain ruangan perpustakaan, pemilihan desain perabot perpustakaan merupakan hal yang penting untuk diperhatikan guna menarik pemustaka datang ke perpustakaan. Bentuk, bahan, dan warna perabot perpustakaan yang fashionable diharapkan dapat memberikan kenyamanan pemustaka. Kebutuhan desain perabot yang dibutuhkan oleh responden pada masing-masing ruangan meliputi bentuk, bahan, dan warna merupakan hal yang perlu mendapat perhatian. Desain perabot yang sesuai dengan selera pemustaka dapat memberikan rasa nyaman selama berada di perpustakaan.

Pendapat sebagian besar responden bahwa perabot meja pada ruang belajar mandiri, ruang multimedia, ruang akses database atau internet, ruang bersama, area pelayanan bantuan dan ruang kerja mahasiswa berbentuk persegi panjang. Persentase terbesar penggunan meja berbentuk persegi panjang terdapat pada 
area pelayanan bantuan (help zone) yaitu, sebesar $89 \%$. Sementara itu, desain perabot meja untuk ruang belajar kelompok dan ruang diskusi berbentuk bulat. Persentase penggunaan meja berbentuk bulat terdapat pada ruang diskusi yaitu, sebesar $67,5 \%$. Peserta diskusi akan merasa nyaman untuk mendengar dan menyampaikan pendapatnya. Di samping itu, bentuk meja yang bulat sebagai penempatan kursi atau tempat duduk lebih efisien sehingga dapat memuat kursi yang lebih banyak.

Menurut pendapat responden, perabot perpustakaan pada setiap ruangan terbuat dengan bahan dasar dari kayu. Sifat perabot dengan bahan dasar dari kayu mempunyai kesan dingin, kuat, dan tahan lebih lama. Persentase penggunaan perabot dengan bahan dasar kayu terdapat pada ruang belajar mandiri yaitu, sebesar $68 \%$. Perabot yang terdapat di Perpustakaan FEB UGM sebagian besar terbuat dari kayu karena merupakan perabot lama yang dicat ulang dengan warna yang menarik. Namun untuk penambahan perabot perpustakaan yang akan datang perlu mempertimbangkan ketersediaan kayu di pasaran. Untuk mendapatkan kualitas kayu yang sebanding dengan perabot yang ada di perpustakaan sangat sulit. Apabila masih ada yang sama kualitasnya, harganya yang tidak terjangkau. Saat ini banyak tersedia perabot dengan bahan dasar besi/logam dikombinasi dengan jenis plastik dengan desain dan warna yang lebih menarik serta harga terjangkau.

Perpaduan warna perabot perpustakaan yang sesuai selera pemustaka dapat menarik seseorang untuk datang ke perpustakaan. Sebagian besar responden menyatakan bahwa warna dasar yang digunakan pada perabot perpustakaan pada setiap ruangan adalah warna biru, kecuali pada ruang kerja mahasiswa sebagian besar responden memilih kombinasi warna coklat dan putih. Meskipun warna coklat diperoleh dengan mencampurkan semua warna primer, yang terdiri dari merah, biru, dan kuning. Persentase penggunaan perabot dengan warna dasar biru terdapat di ruang akses internet atau database yaitu, sebesar $46,5 \%$.

\section{SIMPULAN}

Simpulan penelitian bahwa letak ruangan perpustakaan sudah strategis, sistem pencahayaan di perpustakaan memadai, dan adanya rasa nyaman terhadap sistem pencahayaan di perpustakaan. Keberadaan ruangan perpustakaan sangat bermanfaat selama proses studi di FEB UGM. Sementara itu, penempatan fasilitas perpustakaan terlihat cukup rapi. Namun demikian, ketersediaan komputer di perpustakaan kurang memadai, ketersediaan meja baca dan kursi baca di perpustakaan memadai. Secara umum kondisi fisik perpustakaan cukup menarik. Suasana perpustakaan cukup nyaman dengan sistem tata suara, sistem pencahayaan, dan sistem sirkulasi udara yang ada di perpustakaan. Namun masih perlu menambah beberapa fasilitas ruangan, seperti, meja baca, kursi baca, dan beberapa unit komputer untuk mengakses informasi. Kebutuhan kondisi fisik perpustakaan bagi pemustaka berupa penambahan ruang belajar mandiri yang terpisah dengan ruang lain di perpustakaan merupakan pekerjaan yang harus diprioritaskan. Ketersediaan fasilitas stopkontak listrik serta penambahan kecepatan jaringan internet atau Wi-Fi di setiap ruangan perpustakaan sudah menjadi kebutuhan 
pemustaka. Sebagian besar pemustaka membutuhkan desain perabot perpustakaan yang terdiri dari perabot meja pada ruang belajar mandiri, ruang multimedia, ruang akses database/internet, ruang bersama, area pelayanan bantuan dan ruang kerja mahasiswa berbentuk persegi panjang. Sementara itu desain perabot meja untuk ruang belajar kelompok dan ruang diskusi berbentuk bulat. Bahan dasar perabot terbuat dari kayu serta warna dasar yang digunakan pada perabot perpustakaan pada setiap ruangan adalah warna biru, kecuali pada ruang kerja mahasiswa yaitu kombinasi warna coklat dan putih. Saran bagi peneliti selanjutnya bahwa pemilihan perabot dan sarana prasarana lainnya yang digunakan perpustakaan di masa yang akan datang, sebaiknya memperhatikan kriteria green building.

\section{DAFTAR PUSTAKA}

Achmad, Sutedjo, M., Surono, \& Suprayitno, E. (2012). Layanan cinta: perwujudan layanan prima ++ perpustakaan. Jakarta: Sagung Seto.

Andrews, C., Wright, S. E., \& Raskin, H. (2015). Library learning spaces: Investigating libraries and investing in student feedback. Journal of Library Administration, 56(6), 647-672. https:/ / doi.org/http:/ /dx.doi.org/10 $.1080 / 01930826.2015 .1105556$

Bailin, K. (2011). Changes in academic library space: A case study at the University of New Sooth Wales. Australian Academic and Research Libraries, 42(4), 342-359. Retrieved from http:/ /scihub.tw/https://doi.org/10.1080/000 48623.2011.10722245

Beard, C., \& Bawden, D. (2012). University libraries and the postgraduate:
Physical and virtual spaces. New Library World, 113(9/10), 439-447. Retrieved from http://scihub.tw/https:/ / doi.org/10.1108/030 74801211273911

Chan, D. L. H., \& Spodick, E. (2014). Space development: A case study of HKUST Library. New Library World, 115(5/6), 250-262. Retrieved from http://scihub.tw/https://doi.org/10.1108/NL W-04-2014-0042

Farmer, L. S. J. (2016). Library space: Its role in research. The Reference Librarian, 57(2), 87-99. https://doi.org/https:/ / doi.org/10.1 080/02763877.2016.1120620

Hernon, P. (2016). Five challenges confronting library-related research and researchers. Public Library Quarterly, 35(4), 298-310. https://doi.org/https:/ / doi.org/10.1 080/01616846.2016.1245000

Istiqomah, Z. (2014). Perpustakaan di era keterbukaan informasi: Sebuah tantangan yang harus dihadapi. Visi Pustaka, 16(2), 151-157.

Kumalawati, D. (2015). Fungsi ruang perpustakaan perguruan tinggi berbasis learning commons (Studi di Institut Teknologi Sepuluh Nopember Surabaya dan Perpustakaan Kristen PETRA Surabaya) (Tesis). Sekolah Pasca Sarjana Universitas Gadjah Mada.

Le, X. (2009). Perpustakaan sebagai ruang inkubasi bagi inovasi: Praktek, tren dan seperangkat kemampuan (kompetensi). Visi Pustaka, 11(2), 3238 .

Martoadmojo, K. (2009). Pelayanan bahan pustaka. Jakarta: Universitas Terbuka.

Matthews, G., \& Walton, G. (2014). Strategic development of university library space: Widening the influence. New Library World, 115(5/6), 237-249. Retrieved from http://sci- 
hub.tw/https://doi.org/10.1108/NL W-05-2014-0062

Montgomery, S. E. (2014). Library space assessment: User learning behaviors in the library. The Journal of Academic Librarianship, 40(1), 70-75. Retrieved from http:/ / scihub.tw/https://doi.org/10.1016/j.ac alib.2013.11.003

Motealleh, P., Parsaee, M., \& Sheybani, M. (2015). Investigation the significance of lanscape in designing library by emphasing on the enhancement of learning. HBRC Journal, 11(1), 43-56. https:/ / doi.org/http:/ / dx.doi.org/10 .1016/j.hbrcj.2014.12.007

Niegaard, H. (2011). Library space and digital challenges. Library Trends, 60(1), 174-189. Retrieved from http://scihub.tw/http:/ / dx.doi.org/10.1353/li b.2011.0028

Nitecki, D. A. (2011). Space assessment as a venue for defining the academic library. The Library Quarterly: Information, Community, Policy, 81(1), 27-59. Retrieved from http://scihub.tw/10.1086/657446

Noviani, R., Rusmana, A., \& Rodiah, S. (2014). Peranan desain interior perpustakaan dalam menumbuhkan minat baca pada ruang perpustakaan. Jurnal Kajian Informasi \& Perpustakaan, 2(1), 37-46. Retrieved from http://jurnal.unpad.ac.id/jkip/article /view/11626/5441

Perpustakaan Nasional R.I. (2011). Standar nasional perpustakaan. Jakarta: Perpustakaan Nasional R.I.

Saunders. L. (2016). Room for improvement: Priorities in academic libraries' strategic plans. Journal of Library Administration, 56(1), 1-16. https://doi.org/https://doi.org/10.1
080/019308 26.2015.1105029

Saunders, L. (2015). Academic libraries' strategic plans: Top trends and underrecognized areas. The Journal of Academic Librarianship, 41(3), 285-291. https:/ / doi.org/http:/ / dx.doi.org/10 .1016/jacalib.2015.03.011

Tanloet, P., \& Tuamsuk, K. (2011). Core competencies for information professionals of Thai academic libraries in the next decade (A.D. 2010-2019). The International Information $\mathcal{E}$ Library Review, 43(3), 122-129. Retrieved from http://dx.doi.org/10.1080/10572317. 2011.10762889

Turner, A., Welch, B., \& Reynolds, S. (2013). Learning spaces in academic libraries - a review of the evolving trends. Australian Academic \& Research Libraries, 44(4), 226-234. Retrieved from http://scihub.tw/https://doi.org/10.1080/000 48623.2013.857383

Widjaja, R. R. (2009). Arsitektur perpustakaan perlu dibenahi agar menarik. Retrieved September 21, 2015, from http:/ / promojatengemprovjateng.co $\mathrm{m} /$ detailnews.php?id=10126

Wiratningsih, R. (2015). Perpustakaan perguruan tinggi dan pembelajaran kolaboratif. In Makalah Lomba Penulisan dalam rangka dies Perpustakaan UGM. Yogyakarta.

Yoo-Lee, E. Y., Lee, T. H., \& Velez, L (2013). Planing library space and services for millennials: An Evidencebased approach. Library Management, 34(6/7), 32-38. Retrieved from http://scihub.tw/https://doi.org/10.1108/LM -08-2012-0049 